\title{
Pseudocyesis Leading to Folie-à-Deux
}

\author{
Amit B. Nagdive ${ }^{1}$ Ravi Singh Bhainsora ${ }^{1}$ Rouchelle Fernandes ${ }^{1}$ Prakash B. Behere ${ }^{1} \quad$ Siddharth Sethi ${ }^{1}$ \\ ${ }^{1}$ Department of Psychiatry, Jawaharlal Nehru Medical College, \\ Sawangi, Wardha, Maharashtra, India \\ Address for correspondence Rouchelle Fernandes, MBBS, \\ Department of Psychiatry, Jawaharlal Nehru Medical College, \\ Wardha, Maharashtra, India (e-mail: rouchelle795@gmail.com).
}

J Neurosci Rural Pract 2021;12:419-423.

\begin{abstract}
Keywords

- delusion of pregnancy

- delusional disorder

- shared psychotic disorder

Pseudocyesis or false belief of pregnancy is the emergence of classical manifestations of pregnancy-nausea, breast enlargement and pigmentation, abdominal distention, amenorrhea, and labor pains-in a nonpregnant woman. It is a multifactorial disease and its development is influenced by many different elements such as neuroendocrine, social, psychodynamic, and cultural issues. "Folie-à-deux," is shared psychotic disorder, describes a syndrome in which delusion is transferred to another person who is more susceptible. Both individuals are closely related or know each other for a long time and typically live together in relative social isolation. In its commonest form, the individual who first develops the delusion (the primary case) is often chronically ill and typically is the dominant member in a close relationship with a more suggestible person (the secondary case) who also develops the delusion. Treatment options should also be kept in mind as antipsychotics themselves can increase prolactin levels and can lead to amenorrhoea and galactorrhea and can further strengthen patient's belief about her pregnancy. This case highlights that the most important therapeutic step in the treatment of folie-à-deux is separation of the inducer and the induced. Here we describe a case of folie-à-deux of a married couple in which the female had delusional pregnancy while the husband shared and supported her delusion against substantial medical evidence.
\end{abstract}

\section{Introduction}

Pseudocyesis or false belief of pregnancy is the emergence of classical manifestations of pregnancy-nausea, breast enlargement and pigmentation, abdominal distention, amenorrhea, and labor pains-in a nonpregnant woman. Pseudocyesis illustrates the ability of the psyche to influence the soma, most likely through central input at the level of the hypothalamus. ${ }^{1}$

Extensive analysis on the subject revealed that most of the cases originated in developing countries. Eighty case histories were found. ${ }^{2}$
Pseudocyesis is a multifactorial disorder and its evolution is influenced by many different elements such as neuroendocrine, social, psychodynamic, and cultural issues. ${ }^{3}$ Few case reports have also mentioned pseudocyesis in relation to antipsychotic-associated hyperprolactinemia ${ }^{4-7}$ and metabolic syndrome. ${ }^{8}$

Although in cases of pseudocyesis, single fetus is most commonly reported but often patients may report more than one. ${ }^{9}$

"Folie-à-deux," was devised by Lasegue and Falret in 1877, also known as shared psychotic disorder, is a syndrome in which delusions are transferred from one individual to another. ${ }^{10}$ published online

March 24, 2021
DOI https://doi.org/

$10.1055 / \mathrm{s}-0041-1726615$ ISSN 0976-3147
(C)2021. Association for Helping Neurosurgical Sick People.

This is an open access article published by Thieme under the terms of the Creative Commons Attribution-NonDerivative-NonCommercial-License, permitting copying and reproduction so long as the original work is given appropriate credit. Contents may not be used for commercial purposes, or adapted, remixed, transformed or built upon. (https://creativecommons.org/licenses/by-nc-nd/4.0/). Thieme Medical and Scientific Publishers Pvt. Ltd. A-12, 2nd Floor, Sector 2, Noida-201301 UP, India 
Both pseudocyesis and folie-à-deux are considered to be rare mental illnesses but are often reported in developing countries. It frequently occurs when a married couple was infertile and living in a society that gave much more emphasis on having children. The infertility is often blamed on the woman, due to which she is exposed to social discrimination and substantial distress

We describe a case of folie-à-deux of a married couple in which the female had delusional pregnancy, while the husband shared and supported her delusion against substantial medical evidence.

\section{Case Report}

The case presented to a tertiary care center in Wardha district of Maharashtra state, India, on February 12, 2019. Mrs. A, 37-year-old married woman, housewife, was referred from gynecology department with her husband and sister-in-law. She had visited the hospital five to six times in the past 2 months claiming that she was 6 months pregnant with a single child. Her urine pregnancy test (UPT) and beta-human chorionic gonadotropin were negative and after multiple ultrasonography (USG) abdomen done both in our hospital as well as multiple other centers were not indicative of pregnancy, she was still not willing to believe that she was not pregnant. She believed she could feel the baby kicking in her womb; her belief was further strengthened by her husband who said he could feel the baby kicking whenever he touched her abdomen. Husband also complained that USG was not done properly as radiologist had not scanned the whole abdomen. Sister-in-law after seeing the reports had questioned the couple regarding pregnancy but kept quiet when the couple became adamant and aggressive. They had consulted four times in the gynecology department. After initial consultation and detailed workup when no evidence of pregnancy was found, the patient was subsequently referred to psychiatry department that she refused as she believed she was not mentally ill. But after persistent counselling and on the advice of her sister-in-law she reluctantly agreed.

Mrs. A was the youngest of her three siblings, only female child out of the three and described herself as a shy kid who preferred to stay at home. Her father passed away when she was 12 but refused that it impacted her as she always felt that her father was more close to her brothers. She claims that she was close to her mother and was average in studies.

Mrs. A was married 10 years ago after she ran away from home with her husband. As they belonged to different caste, their parents were not willing to get them married. Mrs. A had known her husband and had an affair for 12 months while they were studying in same BSc. course prior to eloping. Eventually her-in-laws accepted her but her parents never spoke to her again. She got pregnant a year later but had spontaneous abortion in 3 months. In the past 9 years, the couple had tried five times but her pregnancy would not last for more than 3 months. Her-in-laws were supportive of her but gradually they started blaming her as she could not have a child. Her husband always supported her, and when she could not tolerate further verbal abuses from in-laws, much to the protest of her husband, they moved away and started living separately and it had been 2 years since they have been living separately. Her in-laws complained in the past 2 years, the couple had become increasingly isolated and would seldom meet other family members. They also alleged that the husband had always been inclined toward the patient from the beginning and would not listen to anyone else on any other matters. He even left home at her advice and started living separately.

She described her marital relationship as adequate but had noticed that in the past 1 year their interaction had declined. There was no history of any substance use by the husband. Over the past 6 months, the patient had developed increase in appetite and consequently weight gain of $\sim 8 \mathrm{~kg}$ in the initial 3 months. She often felt nauseated and developed bloating sensation. She could also feel the baby kicking and moving in her womb. There was also an enlargement in breast and visible pigmentation. The husband also felt the same way about the patient and took her to various gynecologists. Whenever a doctor would disprove pregnancy, they would just change the doctor, and eventually, they reported to our hospital.

On further interview the patient claimed that she could intermittently hear voice of her baby who would call her maa. Husband also claimed that whenever he would rest his head against her abdomen, he could hear faint sounds/noises that he believed were coming from the baby and it further strengthened his belief about the pregnancy.

The patient also had a sad mood, mainly due to the constant disproval of her pregnancy. However, the patient denied any other symptoms of a major depressive episode including loss of interest in previously pleasurable activities, fatigability, ideas of hopelessness and worthlessness, frequent crying spells, death wishes, and active suicidal ideation.

During interview, the patient did admit that she had irregular menstrual cycles with scanty bleeding that she owed to her doing regular household work during her pregnant state. She blamed her UPTs were faulty and her husband supported this by showing different blogs and reports that he had found on internet claiming that UPT and other routine blood tests did not always detect pregnancy. He also blamed radiologist for not conducting USG properly. The couple alleged that the world had been against them and their relationship from the start and this was a conspiracy and hospital was a part of it. They refused to cooperate and left hospital, but sister-in-law assured us that she would convince them and bring them back for consultation.

They presented a week later (19-02-2019) with in-laws (brother-in-law, sister-in-law, mother-in-law, nephew) and were admitted into psychiatric ward. 


\section{Medical Examination and Laboratory Findings}

The laboratory findings of Mrs. A is given in - Table $\mathbf{1}$.

Table 1 Mrs. A-Ultrasonography abdomen revealed uterus of $60 \mathrm{x}$ $35 \mathrm{~mm}$ in size, empty cavum, clear endometrium $8.4 \mathrm{~mm}$ was seen. The adnexa was echo free.

\begin{tabular}{|c|c|c|}
\hline Test & Specimen & Value \\
\hline Acid phosphatase & Serum & $0-0.07 \mu \mathrm{kat} / \mathrm{L}$ \\
\hline $\begin{array}{l}\text { Activated partial thromboplastin } \\
\text { time }\end{array}$ & Plasma & $31 \mathrm{~s}$ \\
\hline $\begin{array}{l}\text { Adrenocorticotropic } \\
\text { hormone }\end{array}$ & Serum & $8 \mathrm{pmol} / \mathrm{L}$ \\
\hline Albumin & Serum & $39 \mathrm{~g} / \mathrm{L}$ \\
\hline Alkaline phosphatase & Serum & $0.9 \mu \mathrm{kat} / \mathrm{L}$ \\
\hline Alpha fetoprotein & Serum & $13 \mathrm{pg} / \mathrm{L}$ \\
\hline$\delta$-Aminolevulinic acid & Serum & $1.25 \mu \mathrm{mol} / \mathrm{L}$ \\
\hline Aminotransferase, alanine & Serum & $24 \mathrm{U} / \mathrm{L}$ \\
\hline Aminotransferase, aspartate & Serum & $28 \mathrm{U} / \mathrm{L}$ \\
\hline Ammonia & Plasma & $32 \mu \mathrm{mol} / \mathrm{L}$ \\
\hline Amylase & Serum & $86 \mathrm{U} / \mathrm{L}$ \\
\hline Antidiuretic hormone & Plasma & $0.07 \mathrm{pmol} / \mathrm{L}$ \\
\hline \multicolumn{3}{|l|}{ Bilirubin } \\
\hline Direct & Serum & $0.2 \mathrm{mg} / \mathrm{dL}$ \\
\hline Total & Serum & $0.8 \mathrm{mg} / \mathrm{dL}$ \\
\hline \multicolumn{3}{|l|}{ Cholesterol } \\
\hline $\begin{array}{l}\text { High-density lipoprotein } \\
\text { (HDL-C) }\end{array}$ & Plasma & $43 \mathrm{mg} / \mathrm{dL}$ \\
\hline Low-density lipoprotein (LDL-C) & Plasma & $95 \mathrm{mg} / \mathrm{dL}$ \\
\hline Total (TC) & Plasma & $172 \mathrm{mg} / \mathrm{dL}$ \\
\hline \multicolumn{3}{|l|}{ Cortisol } \\
\hline At 5 PM & Serum & $7 \mu \mathrm{g} / \mathrm{dL}$ \\
\hline At $8 \mathrm{AM}$ & Serum & $11 \mu \mathrm{g} / \mathrm{dL}$ \\
\hline $\begin{array}{l}\text { After overnight } \\
\text { suppression test }\end{array}$ & Serum & $3 \mu \mathrm{g} / \mathrm{dL}$ \\
\hline C-peptide & Serum & $2.1 \mathrm{ng} / \mathrm{mL}$ \\
\hline C-reactive protein & Serum & $0.1 \mathrm{mg} / \mathrm{dL}$ \\
\hline $\begin{array}{l}\text { C-reactive protein, highly } \\
\text { sensitive }\end{array}$ & Serum & $0.07 \mathrm{mg} / \mathrm{L}$ \\
\hline Creatine kinase & Serum & $58 \mathrm{U} / \mathrm{L}$ \\
\hline Creatinine & Serum & $0.9 \mathrm{mg} / \mathrm{dL}$ \\
\hline $\begin{array}{l}\text { Erythrocyte sedimentation } \\
\text { rate }\end{array}$ & Blood & $11 \mathrm{~mm} / \mathrm{h}$ \\
\hline Erythropoietin & Serum & $10.5 \mathrm{IU} / \mathrm{L}$ \\
\hline Estradiol & Serum & $102 \mathrm{pg} / \mathrm{mL}$ \\
\hline Ferritin & Serum & $98 \mu \mathrm{g} / \mathrm{L}$ \\
\hline$\alpha$-Fetoprotein & Serum & $12 \mathrm{pg} / \mathrm{L}$ \\
\hline \multicolumn{3}{|l|}{ Folate (folic acid) } \\
\hline RBC & Blood & $330 \mathrm{ng} / \mathrm{mL}$ \\
\hline Serum & Serum & $9.2 \mathrm{ng} / \mathrm{mL}$ \\
\hline $\begin{array}{l}\text { Follicle-stimulating } \\
\text { hormone }\end{array}$ & Serum & $11.4 \mathrm{mlU} / \mathrm{mL}$ \\
\hline
\end{tabular}

(Continued)
Table 1 (Continued)

\begin{tabular}{|l|l|l|}
\hline Test & Specimen & Value \\
\hline Glucose & & \\
\hline 2-h postprandial & Plasma & $120 \mathrm{mg} / \mathrm{dL}$ \\
\hline Fasting & Plasma & $98 \mathrm{mg} / \mathrm{dL}$ \\
\hline Hemoglobin & Blood & $13.5 \mathrm{~g} / \mathrm{dL}$ \\
\hline \multicolumn{1}{|c|}{ Hemoglobin $\mathrm{A}_{1 \mathrm{c}}$} & Blood & $5.2 \%$ \\
\hline $\begin{array}{l}\text { Human chorionic gonadotropin, } \\
\text { quantitative }\end{array}$ & Serum & $3 \mathrm{mIU} / \mathrm{mL}$ \\
\hline Luteinizing hormone & Serum & $14 \mathrm{IU} / \mathrm{L}$ \\
\hline Parathyroid hormone & Serum & $38 \mathrm{ng} / \mathrm{L}$ \\
\hline $\begin{array}{l}\text { Parathyroid hormone-related } \\
\text { peptide }\end{array}$ & Plasma & $1.2 \mathrm{pmol} / \mathrm{L}$ \\
\hline pH & Blood & 7.40 \\
\hline Platelet count & Blood & $180 \times 10^{3} / \mathrm{\mu L}$ \\
\hline Potassium & Serum & $4.1 \mathrm{mEq} / \mathrm{L}$ \\
\hline Progesterone & Serum & $8 \mathrm{ng} / \mathrm{mL}$ \\
\hline Prolactin & Serum & $11 \mathrm{\mu g} / \mathrm{L}$ \\
\hline Testosterone & Serum & $55 \mathrm{ng} / \mathrm{dL}$ \\
\hline Thyroid-stimulating hormone & Serum & $2.4 \mathrm{mIU} / \mathrm{L}$ \\
\hline Thyroxine $\left(\mathrm{T}_{4}\right)$ & & \\
\hline Free & Serum & $1.2 \mathrm{ng} / \mathrm{dL}$ \\
\hline Total & Serum & $8 \mathrm{\mu g} / \mathrm{dL}$ \\
\hline & & \\
\hline
\end{tabular}

The findings laboratory tests of Mr. B is given in - Table 2 .

Table 2 Mr. B-Routine blood test apart from slightly raised liver enzymes (OT: PT 1:3) was within normal limits.

\begin{tabular}{|c|c|c|}
\hline Test & Specimen & Value \\
\hline Alkaline phosphatase & Serum & $0.7 \mu \mathrm{kat} / \mathrm{L}$ \\
\hline$\delta$-Aminolevulinic acid & Serum & $1.32 \mu \mathrm{mol} / \mathrm{L}$ \\
\hline Aminotransferase, alanine & Serum & $28 \mathrm{U} / \mathrm{L}$ \\
\hline Aminotransferase, aspartate & Serum & $91 \mathrm{U} / \mathrm{L}$ \\
\hline Ammonia & Plasma & $38 \mu \mathrm{mol} / \mathrm{L}$ \\
\hline Amylase & Serum & $94 \mathrm{U} / \mathrm{L}$ \\
\hline Antidiuretic hormone & Plasma & $0.09 \mathrm{pmol} / \mathrm{L}$ \\
\hline \multicolumn{3}{|l|}{ Bilirubin } \\
\hline Direct & Serum & $0.3 \mathrm{mg} / \mathrm{dL}$ \\
\hline Total & Serum & $1 \mathrm{mg} / \mathrm{dL}$ \\
\hline \multicolumn{3}{|l|}{ Cholesterol } \\
\hline High-density lipoprotein & Plasma & $36 \mathrm{mg} / \mathrm{dL}$ \\
\hline Low-density lipoprotein & Plasma & $112 \mathrm{mg} / \mathrm{dL}$ \\
\hline Total (TC) & Plasma & 194 mg/dL \\
\hline C-reactive protein & Serum & $0.3 \mathrm{mg} / \mathrm{dL}$ \\
\hline $\begin{array}{l}\text { C-reactive protein, highly } \\
\text { sensitive }\end{array}$ & Serum & $0.09 \mathrm{mg} / \mathrm{L}$ \\
\hline Creatine kinase & Serum & $64 \mathrm{U} / \mathrm{L}$ \\
\hline Creatinine & Serum & $0.7 \mathrm{mg} / \mathrm{dL}$ \\
\hline $\begin{array}{l}\text { Erythrocyte sedimentation } \\
\text { rate }\end{array}$ & Blood & $9 \mathrm{~mm} / \mathrm{h}$ \\
\hline RBC & Blood & $330 \mathrm{ng} / \mathrm{mL}$ \\
\hline Serum & Serum & $9.2 \mathrm{ng} / \mathrm{mL}$ \\
\hline
\end{tabular}


Table 2 (Continued)

\begin{tabular}{|l|l|l|}
\hline Test & Specimen & Value \\
\hline Glucose & & \\
\hline 2-h postprandial & Plasma & $112 \mathrm{mg} / \mathrm{dL}$ \\
\hline Fasting & Plasma & $85 \mathrm{mg} / \mathrm{dL}$ \\
\hline Hemoglobin: & Blood & $14 \mathrm{~g} / \mathrm{dL}$ \\
\hline Hemoglobin $\mathrm{A}_{1 c}$ & Blood & $4.2 \%$ \\
\hline Platelet count & Blood & $192 \times 10^{3} / \mu \mathrm{L}$ \\
\hline Potassium & Serum & $4.5 \mathrm{mEq} / \mathrm{L}$ \\
\hline Testosterone & Serum & $755 \mathrm{ng} / \mathrm{dL}$ \\
\hline $\begin{array}{l}\text { Thyroid-stimulating hormone } \\
(\text { TSH) }\end{array}$ & Serum & $2.8 \mathrm{mlU} / \mathrm{L}$ \\
\hline Thyroxine $\left(\mathrm{T}_{4}\right)$ & & \\
\hline Free & Serum & $1.6 \mathrm{ng} / \mathrm{dL}$ \\
\hline Total & Serum & $10 \mu \mathrm{g} / \mathrm{dL}$ \\
\hline
\end{tabular}

\section{Physical Findings}

Height $1.61 \mathrm{~m}$, weight $64 \mathrm{~kg}$, cardiorespiratory compensation. The skin and visible mucosa were well perfused, abdomen was slightly above the chest level, slightly distended, soft and insensitive, increased pigmentation along the medial line (linea nigra) was seen. Neurological status was normal, no neurologic events.

No significant physical finding noticed in husband Mr. B

\section{Mental Status Examination}

Mrs. A-conscious, oriented toward herself, other persons, to place, and oriented in time. Verbal communication established, with some delay in response, giving short answers. Thought revealed delusion of pregnancy and delusion of persecution. Mood was sad and affect was depressed. Perceptual abnormality in the form of auditory hallucination 2nd person of her baby calling to her ("maa") from womb heard in both the ears, clearly and equally. Insight was absent.

Mr. B-conscious oriented to time, place, and person. Verbal communication established. Thought revealed delusional belief that his wife was pregnant. Mood and affect were anxious. Insight was absent.

\section{Course during Hospital Stay}

The couple was admitted in psychiatric ward and was separated. Mrs. A was started on Tab. Quetiapine and dose was gradually titrated to $600 \mathrm{mg}$ during her 3 weeks stay. In the initial 7 days, no improvement was seen and patient refused to see her relatives and would become irritable on seeing them. She often refused food. During second week of admission, patient became much calmer and agreed to see her relatives. Gradually toward the third week in planned psychotherapy sessions conducted with Mrs. A alone, sessions along with Mr. B, patient's delusion seemed to falter along when diagnostic blood reports and USG reports that she had not believed earlier were explained to her. Mr. B played a significant role during sessions (who had improved) in convincing the patient against her false belief. Mrs. A admitted that she felt alone when her husband left for work and often blamed herself for her inability to sustain pregnancy. She often felt inadequate during family functions and therefore had stopped attending them. Significant improvement was noted in patients toward the end of 3 weeks, her auditory hallucinations had stopped, mood had improved and she no longer believed that she was pregnant.

She was discharged on March 13, 2019 when the patient and relatives requested that they wanted to continue treatment on outpatient basis.

Mr. B was started on Tab Olanzapine and dose was gradually titrated to $15 \mathrm{mg}$. Mr. B initially was angry on separation from his wife but was much more co-operative. Improvement was seen in the initial 10 days when in psychotherapy session Mr. B admitted that it was his deep-seated desire to be a father, and he often felt frustrated and depressed when he saw his coworkers talk about their kids or when he attended their birthday parties. When confronted with test reports indicative that his wife was not pregnant, Mr. B initially was confrontational but eventually came to terms with reality. He played a much bigger role during planned psychotherapy sessions with the wife and toward the end of 3 weeks stay $\mathrm{Mr}$. B was relatively asymptomatic and was discharged on request with his wife.

After 2 months, Mrs. A with her husband moved back to her in-laws and have been regularly compliant. On subsequent follow-ups first fortnightly and then monthly both have been relatively asymptomatic.

\section{Discussion}

Folie-à-deux is characterized by the transfer of delusions from one person to another. Both persons are closely associated for a long time and typically live together in relative social isolation. In its most common form, the individual who first has the delusion (the primary case) is often chronically ill and typically is the influential member in a close relationship with a more suggestible person (the secondary case) who also develops the delusion. The person in the secondary case is frequently less intelligent, more gullible, more passive, or more lacking in self-esteem than the person in the primary case. If the pair separates, the secondary person may abandon the delusion, but this outcome is not seen uniformly. ${ }^{1}$

The duo who presented clearly fit the diagnosis of folie-à-deux with Mrs. A, the wife, who is clearly the dominant partner in the relationship. In this case, it is clear that Mrs. A was the inducer who first developed delusional pregnancy, while Mr. B was induced one who was over dependent on the wife. Gradually as they begin to live in social isolation, away from family members and friends may have influenced the development of shared psychosis.

Treatment options should also be kept in mind as antipsychotics themselves can increase prolactin levels and can lead to amenorrhoea and galactorrhea and can further strengthen patient's belief about her pregnancy. 
Of note was the significant and early improvement in $\mathrm{Mr} \mathrm{B}$ when the duo was separated.

\section{Conclusion}

Perhaps the most important therapeutic step in the treatment of folie-à-deux is separation of the inducer and the induced. This case clearly demonstrates that treatment options and separating the duo lead to significant improvement in the induced and the induced can have a significant role to play in breaking the delusional belief system of the inducer.

\section{Conflict of Interest}

None declared.

\section{References}

1 Sadock BJ, Kaplan HI, Sadock VA, Kaplan \&Sadock's Synopsis of Psychiatry. Philadelphia: Lippincott Williams \& Wilkins; 2007

2 Seeman MV. Pseudocyesis, delusional pregnancy, and psychosis: the birth of a delusion. World J Clin Cases 2014;2(8): 338-344
3 Azizi M, Elyasi F. Biopsychosocial view to pseudocyesis: a narrative review. Int J Reprod Biomed (Yazd) 2017;15(9):535-542

4 Grover S, Sharma A, Ghormode D, Rajpal N. Pseudocyesis: a complication of antipsychotic-induced increased prolactin levels and weight gain. J Pharmacol Pharmacother 2013; 4(3):214-216

5 Ahuja N, Moorhead S, Lloyd AJ, Cole AJ. Antipsychoticinduced hyperprolactinemia and delusion of pregnancy. Psychosomatics 2008;49(2):163-167

6 Cramer B. Delusion of pregnancy in a girl with drug-induced lactation. Am J Psychiatry 1971;127(7):960-963

7 Shankar R. Delusion of pregnancy in schizophrenia. $\mathrm{Br} \mathrm{J}$ Psychiatry 1991;159:285-286

8 Manjunatha N, Saddichha S. Delusion of pregnancy associated with antipsychotic induced metabolic syndrome. World J Biol Psychiatry 2009;10(4 Pt 2):669-670

9 Bera SC, Sarkar S. Delusion of pregnancy: a systematic review of 84 cases in the literature. Indian J Psychol Med 2015;37(2): 131-137

10 Lasègue C, Falret J. La folie à deux. Ann Med Psychol (Paris) 1877;18:321-355 